\title{
Anti-nutrients and heavy metals in some new plantain and banana cultivars
}

\author{
Adeniji, T.A.*, Sanni, L.O.**, Barimalaa, I.S.*, and Hart, A.D.* \\ *Department of Food Science and Technology, Rivers State \\ University of Science and Technology, P.M.B. 5080, Nkpolu, Port Harcourt, Nigeria. \\ **International Institute of Tropical Agriculture, High Rainfall Station, Onne, P.M.B. 008, Nchia-Eleme, \\ Port Harcourt, Nigeria. \\ *Address for Correspondence: Email: tiradeniyi@yahoo.com
}

\begin{abstract}
Plantain and banana flour are important raw material in the baking and confectionery industry, and complementary food formulation. Five new plantain and banana hybrids developed by the International Institute of Tropical Agriculture (IITA) at Highrainfall Station, Onne, Nigeria were screened for certain anti-nutritional factors and some heavy metals commonly found in foods. Results show that PITA 17 is lowest (1.66\%) in saponin, while PITA 24 $(4.97 \%)$ is highest. Conversely, the tannin content was lowest $(0.16 \%)$ in PITA 24 and highest $(0.28 \%)$ in both

cultivars evaluated. Phytate level was lowest $\left(1.2 \times 10^{-5}\right)$ in PITA 14 and highest $\left(11.0 \times 10^{-5}\right)$ in PITA 24. PITA's 14, 24 and Agbagba contained 4.0x $10^{-5} \%$ cyanide, while 4.0x $10^{-5}$ was obtained for PITA's 17, 26 and BITA 3. The phenolic content of PITA's 14 and 26, and Agbagba was $0.033 \%$, while PITA's 17,24 and BITA 3 had $0.036 \%$. The heavy metal contents of the new plantain and banana ranges between $0.13-0.19 \mathrm{ppm}$ for Lead, $0.02-0.03 \mathrm{ppm}$ for cadmium, and $<0.01$ for mercury, across the six cultivars investigated.
\end{abstract} PITA 17 and BITA 3. The oxalate content of the new hybrid ranges between $0.49 \%$ and $0.82 \%$, across the six
Key words: Hybrids, flour, industry, anti-nutritional factors, heavy metals.

\section{INTRODUCTION}

$\mathbf{P}$ lantain and banana (Musa spp.) are major starchy staples in the local food economies of sub-Saharan Africa, providing more than 25\% of the carbohydrates and $10 \%$ of the daily calorie intake for more than 70 million people in the continent IITA (2000). The International Institute of Tropical Agriculture (IITA) began research on plantain and banana in 1973 and has made progress in the areas of host plant resistance to black Sigatoka, through the development of improved hybrids, improved cropping systems, diversified post harvest utilization and rapid multiplication of planting materials.

Dissemination of these novel technologies commenced in 2000 , with a focus on plantain growing belts of Nigeria.

Plantain and banana processing is a means of adding value, increasing product diversification, utilization and enhancing the market price of the new hybrids. Adeniji and Empere (2001) reported that the conversion of cooking banana into flour was a means of adding value to the fruit as well as extending shelf life and facilitating transportation. One interesting trend is that plantain flour is currently being exploited in baking and complementary weaning 
foods in Nigeria (Ogazi, 1996; Adeniji and Empere, 2001; Baiyeri, 2004). Plantain and banana flour is currently on sale in several cities in southern Nigeria, which is a strong indication that farmers and plantain processors are beginning to adopt processing options as a means of market diversification and consequently curtailing glut. However, information is required on the level of anti-nutrient factors and other toxicants, especially in the new hybrids. The wild banana parent used in obtaining new varieties might confer genes with high anti-nutrient into the new hybrids. Moreover, seasonal changes during fruit development could also have impact on the nutritional value of flour so produced from the new hybrids. Chandler (1995), Baiyeri (2000) and Baiyemm thick to enhance dehydration. Sliced fruits were carefully dried in Forced-Air Sanyo Gallenkamp Moisture Extraction Oven at $65^{\circ} \mathrm{C}$ for about 48 hours and milled with the aid of stainless Kenwood Chef Warring Blender, Model KM001 (0067078) series. The antinutrient content and heavy metals in the flour were determined using AOAC (1990) procedures. All chemical analysis was performed in the Plant Anatomy and Physiology Research Laboratory, Faculty of Science, University of Port Harcourt, Herbarium, Port Harcourt, Nigeria.

\section{RESULTS AND DISCUSSION}

Tables 1 and 2 present the anti-nutrient and heavy metals in some new plantain and banana cultivars. From the tables, PITA 24 had $4.97 \%$ saponin, which is higher than the sample mean, and also higher than the previous $0.023 \%$ obtained in bitter leaf (Apena et al., 2004). However, Merck, Index (1976) reported that saponins are practically non-toxic to man when taken orally. Saponins have a number of advantages, of which, the most interesting is that it can lower plasma cholesterol concentrations
(Oakenfull, et al., 1979 and Topping, et al., 1980). The bitter taste of oil bean seed is due partly to saponin glycoside (Achinewhu, 1983). This suggests that plantain hybrids may be consumed without any hazardous effect. PITA 24 had the lowest $(0.16 \%)$ tannin content, while both PITA 17 and BITA 3 contained the highest $(0.28 \%)$. Earlier report $(0.023 \%$ tannin in bitter leaf) by Apena et al., (2004) is comparable to the present data. However, a fairly higher levels ( 0.77 and $0.89 \%$ ) was reported in food legumes, chick peas and black grams, respectively (Duhan, et al., 1989; Van der Poel, 1990). The oxalate (0.49$0.82 \%$ ) contents of the new Musa hybrids are also comparable to $0.067-0.197 \mathrm{mg} / 100 \mathrm{~g}$ FW reported for wild yam tubers (Bhandari and Kawabata, 2004). The phytate contents of between $1.2 \times 10^{-}$ $5 \%$ and $11.0 \times 10^{-5} \%$ were obtained across the cultivars, which is much lower than $0.007 \%$ estimated in bitter leaf (Apena, et al., 2004) and are also lower than the values of $0.47 \%, 0.4 \%$ and $0.16 \%$ earlier obtained for yam, cassava, and maize, respectively (Adeyeye, et al., 2000). Duhan, et al., 1989 and Van der Poel, (1990) had earlier obtained higher levels of phytic acid $(0.97 \%$ and $1.1 \%)$ in chick peas and black grams, respectively. The phytate levels are also lower than $0.29 \%$ found in bambara groundnut and $0.2 \%$ in pigeon pea (Igbedioh, et al., 1994). Bhandari and Kawabata (2004) has also reported a higher phytate levels (as phytic acid) ranges from $0.18-0.36 \%$ DM in wild yam tubers. PITA's 14, 24 and Agbagba contained 4.0x10 $0^{-5} \%$ cyanide, while $4.0 \times 10^{-5}$ was obtained for PITA's 17, 26 and BITA3. These values are much lower compared to 3.2-6.0 mg HCN equivalents per $\mathrm{kg}$ fresh weight of wild yam tubers (Bhandari and Kawabata (2004). The cyanogen contents of wild yam tubers (Bhandari and Kawabata, (2004) was reported to be notably lower than those reported in wild cassava (Nassar and Fichtner, 1978) and reported for various food 
sources (Rezaul and Bradbury, 2002). Results obtained in this present study indicated that the cyanogen levels found in new plantain and banana cultivars were satisfactorily below the safety level for cyanide poisoning. The lethal dose range for humans, of $\mathrm{HCN}$ ingested, is estimated to be only $0.5-3.5 \mathrm{mg} / \mathrm{kg}$-body weight (Bradbury, 1991). Earlier, Montgomery (1980) reported that the presence of this smaller amount of cyanogen may have some long-term adverse effects on human health, which is a strong proof that cyanogen ingestion can give rise to chronic neurological disease in humans. The present study also revealed that PITA's 14, 26 and Agbagba contained $0.033 \%$ phenols, while 0.036 was found in PITA's 17, 24 and BITA 3. The lead content of the new plantain and banana ranges from $0.13-0.19 \mathrm{ppm}$, and 0.02 -ri and Unadike (2001) reported that nutritional values of Musa spp. fruits vary with cultivars, stage of ripeness, soil, and climatic conditions under which the fruits were cultivated. New plantain and banana may contain certain levels of antinutrients, which could hinder the efficient utilization, absorption or digestion of nutrients and thus, reduce their bio-availability and their nutritional qualities. Studies have shown some anti-nutritional factors present in plantain and banana, but there is no published report on the anti-nutritional factors and heavy metal status of new Musa hybrids being currently disseminated in Nigeria. Deleterious effect of anti-nutrients and heavy metals on humans has been widely investigated. For example, tannins inhibit the digestibility of protein and phytic acid reduces the bio-availability of some essential minerals (Duhan et al., 1989; Van der Poel, 1990), while oxalic acid and its salts has been implicated in decreasing calcium absorption and aiding the formation of kidney stones (Noonan and Savpeeled manually with the aid of stainless kitchen knife and pulps sliced longitudinally to groups of people (Libert and Franceschi, 1987). The majority of urinary stones formed in humans are calcium oxalate stones (Hodgkinson, 1977). Patients are advised to limit their intake of foods with a total intake of oxalate not exceeding 50$60 \mathrm{mg}$ per day (Massey et al., 2001). Phytic acid forms complexes with proteins (protein-phytate complex) (Cheryan, 1980) and chelates essential dietary minerals such as iron, zinc, calcium and magnesium, thus decreasing their utilization (Kratzer, 1965). Heavy metals can be found naturally in the environment in trace amounts, but industrial activities can lead to pollution and increase their levels. Effluent from oil and gas exploration, which are very prominent in the Niger Delta areas of Nigeria, including Rivers State are discharged into rivers. These wastes eventually find their way into the food chain, where aquatic and terrestrial animals and plants accumulate them in their tissue or cells. The Plantain and Banana Improvement Programme of the International Institute of Tropical Agriculture is cited in Onne, Rivers State. Newly developed plantain and banana hybrids and its associated technologies are being massively disseminated to farming systems in eleven states of Nigeria, including the host state. Information on anti-nutrient and heavy metal status of these hybrids is lacking. This research was articulated to establish antinutrient and heavy metal status of new plantain and banana developed at IITA to complement adoption.

\section{MATERIALS AND METHODS}

Five cultivars of new plantain and banana released to the farming systems in Nigeria were investigated, including the check, Agbagba. Green matured bunches were obtained from the experimental station of the International Institute of Tropical Agriculture, Onne, Port Harcourt. Three fruits were collected from the second hand of the proximal end of the bunch, washed and 
peeled manually with the aid of stainless kitchen knife and pulps sliced longitudinally to about 15 $0.03 \mathrm{ppm}$ for cadmium, while the mercury content was $<0.01 \mathrm{ppm}$ for all the cultivars accessed, which are in consonance with $0.01 \mathrm{mg} / \mathrm{kg}$ $0.006 \mathrm{mg} / \mathrm{kg}$ lead, cadmium, mercury and chromium levels reported in some sea foods (Wordu, 2004) in Rivers State waters. These levels of heavy metals is a clear indication that new plantains and bananas are safe for human consumption and do not constitute health hazard. Expectedly, the heavy metal contents of the new plantain and banana are very low, especially mercury. Reduction of anti-nutrients in foods may be necessary especially when their levels are higher than those generally regarded as safe for human consumption. This can be accomplished through different hydrothermal treatments, which also enhances the nutritional qualities, increase palatability and digestibility of foods. The results established in this present study suggest that new plantain and banana are probably not deleterious to human health, with respect to the anti-nutrient and heavy metals investigated. The effect of phytic acid is highly detrimental to the CGIAR's (Consultative Group on International Agricultural Research) 'Harvest Plus' initiative, aimed at improving the micronutrient concentration ( $\mathrm{Fe}, \mathrm{Zn}$, and provitamin A) in her mandate crops, including plantain and cassava, maize, and yam. IITA is at the center of this project, which calls for more investigations in the new hybrids and their products.

Table 1. Anti-nutrients in plantain and banana flour using the pulp at harvest

\begin{tabular}{lcccccc}
\hline & \multicolumn{5}{c}{ Antinutrient (\%) } \\
\cline { 2 - 6 } Cultivars & Saponin & Tannin & Oxalate & Phytate & Cyanide & Phenolic compound \\
\hline PITA 14 & 2.60 & 0.22 & 0.72 & $1.2 \times 10^{-5}$ & $4.0 \times 10^{-5}$ & 0.033 \\
PITA 17 & 1.66 & 0.28 & 0.49 & $5.0 \times 10^{-5}$ & $8.0 \times 10^{-5}$ & 0.036 \\
PITA 24 & 4.97 & 0.16 & 0.82 & $11.0 \times 10^{-5}$ & $4.0 \times 10^{-5}$ & 0.036 \\
PITA 26 & 1.96 & 0.24 & 0.49 & $4.5 \times 10^{-5}$ & $8.0 \times 10^{-5}$ & 0.033 \\
BITA 3 & 1.73 & 0.28 & 0.51 & $4.5 \times 10^{-5}$ & $8.0 \times 10^{-5}$ & 0.036 \\
AGBAGBA & 1.70 & 0.26 & 0.49 & $6.8 \times 10^{-5}$ & $4.0 \times 10^{-5}$ & 0.033 \\
Mean & 2.44 & 0.24 & 0.59 & $3.85 \times 10^{-5}$ & $6.4 \times 10^{-5}$ & 0.035 \\
SE & 0.53 & 0.02 & 0.059 & 9.21 & 8.94 & 0.00067 \\
\hline
\end{tabular}


Table 2. Heavy metals in plantain and banana flour using the pulp at harvest

\begin{tabular}{llll}
\hline & \multicolumn{3}{c}{ Heavy metal $(\mathbf{p p m})$} \\
\cline { 2 - 4 } Cultivar & Lead & Cadmium & Mercury \\
\hline PITA 14 & 0.17 & 0.02 & $<0.01$ \\
PITA 17 & 0.18 & 0.03 & $<0.01$ \\
PITA 24 & 0.15 & 0.02 & $<0.01$ \\
PITA 26 & 0.18 & 0.02 & $<0.01$ \\
BITA 3 & 0.19 & 0.03 & $<0.01$ \\
AGBAGBA & 0.13 & 0.02 & $<0.01$ \\
Mean & & & 0.01 \\
SE & 0.17 & 0.02 & 0.00 \\
\hline
\end{tabular}




\section{REFERENCES}

Achinewhu, S.C. (1983). The saponins content of some Nigerian seeds. Qual. Plant, Plant Foods Hum. Nutr. 33: 3-9.

Adeniji, T.A. and Empere, C.E. (2001). The development, production and quality evaluation of cake made from cooking banana flour. Global Journal of Pure and Applied Sciences, 7 (4): 633 635.

Adeyeye, E.I., Arogundade, L.A., Akintayo, E.T., Aisida, O.A., and Alao, P.A. (2000). Calcium, zinc, and phytate interrelationships in some foods of major consumption in Nigeria. Food Chemistry, 71: 435-441.

AOAC (1990). Official Methods of Analysis, Washington DC, USA: Association of Official Analytical Chemists.

Apena, A., Amore, T.O., and Shaibu, N. (2004). Nutrient and antinutrient composition of Vernonia amygdalina (bitter leaf). In: (G.O. Adegoke, L.O. Sanni, K.O. Falade and P.I. UzoPeters, eds.). Current challenges in the food industry in Nigeria, Proceedings of the 28th annual conference/AGM,Nigerian Institute of Food Science and Technology, University of Ibadan, Ibadan Nigeria, 12-14 October, 2004, p 164.

Baiyeri, K.P. (2000). Effect of nitrogen fertilization on mineral concentration in plantain (Musa sp. AAB) fruit peel and pulp at unripe and ripe stages. Plant Product Research Journal, 5: $38-43$.

Baiyeri, K.P. and Unadike, G.O. (2001). Ripening stages and days after harvest influenced some biochemical properties of two Nigerian plantains (Musa species AAB)cultivars. Plant Product Research Journal, 6: 11-19.
IITAAnnual Report (2000) Project 2, Improving Plantain and Banana Based Systems. International Institute of Tropical Agriculture, (IITA), Ibadan, Nigeria.

Kratzer, F.H. (1965). Soyabean protein-mineral interrelationship. Food Proc. Ed. Am. Sc. Exper. Biol, 24: 1492.

Libert, B., and Franceshi, V.R. (1987). Oxalate in crop plants. Journal of Agriculture and Food Chemistry, 35 (6): 926-937.

Massey, L.K., Palmer, R.G., and Horner, H.T. (2001). Oxalate content of soybean seeds (Glycine max: Leguminosae), Soya foods, and other edible legumes. Journal of Agriculture and Food Chemistry, 49: 4262-4266.

Merck Index (1976). 9th edn, M. Merck, Rahway, p. 8120.

Montgomery, R.D. (1980). Cyanogens, Academic Press, New York.

Nassar, N.M., and Fichtner, S.S. (1978). Hydrocyanic acid content in some wild Manihot (Cassava) species. Canadian Journal of Plant Science, 58: 577-578.

Noonan, S.C., and Savage, G.P. (1999). Oxalic acid and its effects on humans. Asia Pacific Journal of Clinical Nutrition, 8: 64-74.

Oakenfull, D.G., Fenwick, D.E., Hood, R.L., Topping, D.L., Illman, R.J. and Storer, G.B. (1979). Effects of saponins on bill acids and plasma lipids in the rat. Br. J. Nutr., 42: 209216.

Ogazi, P.O. (1996). Plantain: production, processing and utilisation. Paman Associates Ltd., Imo State, Nigeria, p. 305. 
Rezaul, H.M., and Bradbury, J.H. (2002). Total cyanide determination of plants and foods using the picrate and acid hydrolysis methods. Food Chemistry, 77(1): 107-114.

Topping, D.L., Stover, G.B., Calvert, G.D. and Meller, R.A. (1980). Effects of dietary saponins on fecal bile acids and neutral sterols, plasma lipids and lipoprotein turnover in the pig. Am. J. Clin. Nutr. 33: 783-786.

Van der Poel, A.F.B. (1990). Effect of processing on antinutritional factors and protein nutritional value of dry beans. Animal Feed Science and Technology, 2: 179-208.

Wordu, G.O. (2004). Heavy metals in some seafoods obtained from Rivers State waters. In: (G.O. Adegoke, L.O. Sanni, K.O. Falade and P.I. Uzo-Peters, eds.). Current challenges in the food industry in Nigeria, Proceedings of the 28th annual conference/AGM, Nigerian Institute of Food Science and Technology, University of Ibadan, Ibadan Nigeria, 12-14 October, p 164.

Baiyeri, T.G. (2004). Evaluation of mulimixes and porridges made from maize (Zea mays), soybean (Glycine max) and plantain (landrace and hybrid Musa AAB) flour for use as complementary food. MSc. Dissertation, Department of Home Science, Nutrition and Dietetics, University of Nigeria, Nsukka, Nigeria, Unpublished Data, p 71.
Bhandari, M.R., and Kawabata, J., (2004). Organic acid, phenolic content and antioxidant activity of wild yam (Dioscorea spp.) tubers of Nepal. Food Chemistry, 88: 163-168.

Bradbury, J.H. (1991). Properties and analysis of antinutritional factors in foods. ASEAN Food Journal, 6(4): 123-128.

Chandler, S. (1995). The nutritional value of bananas. In: Gowen, S. (ed.). Bananas and Plantains. Chapman and Hall, 2-6 Boundary Row, London SE1 8HN, UK. p. 597.

Cheryan, M. (1980). Phytic Acid interactions in food systems. CRC Crit. Rev. Food Sci. Nutr., 13: 297-335.

Duhan, A.B.M., Chauhan, D. and Kapoor, A.C. (1989). Phytic acid contents of chickpea and black gram. Varietal difference and effect of domestic processing and cooking methods. Journal of the Science of Food and Agriculture, 49: 449-455.

Hodgkinson, A. (1977). Oxalic acid in biology and medicine, Academic Press London.

Igbedioh, S.O., Olugbemi, K.T., and Akpapunam, M.A. (1994). Effects of processing methods on phytic acid level and some constituents in bambara groundnut (Vigna subterranean) and pigeon pea (Cajanus cajan). Food Chemistry, 50: 147-151. 